\title{
JUECES, REPRESIÓN Y JUSTICIA TRANSICIONAL EN ESPAÑA, CHILE Y ARGENTINA
}

\section{JUDGES, REPRESSION AND TRANSITIONAL JUSTICE IN SPAIN, CHILE AND ARGENTINA}

\author{
Paloma Aguilar paguilar@poli.uned.es \\ Universidad Nacional de Educación a Distancia (UNED). España
}

\begin{abstract}
RESUMEN
¿Por qué algunas democracias han avanzado tanto en el esclarecimiento y la persecución judicial de las violaciones de derechos humanos cometidas por las dictaduras precedentes, mientras que otras mantienen vigentes leyes de amnistía que impiden -0 , al menos, dificultan — la aprobación de dichas medidas? Nos proponemos demostrar que, durante los procesos de democratización, cuanto más "legal" haya sido la represión dictatorial, y mayor sea la implicación de los jueces en ella, mayor resistencia existirá a la aplicación de políticas de justicia transicional. Nos proponemos comparar el caso español con el chileno y el argentino. En los tres países hubo dictaduras de corte conservador, la violación de derechos humanos fue sistemática y, cuando se democratizaron, tuvieron que reflexionar sobre qué hacer con este pasado de violencia política. Una vez que la democracia se ha consolidado, factores adicionales contribuirán a explicar la presencia 0 ausencia de rendición de cuentas en el ámbito judicial.
\end{abstract}

\section{Palabras Clave}

Dictaduras; Justicia transicional; Represión política; Sistema judicial.

\section{Abstract}

Why have some democracies made considerable progress in elucidating and prosecuting human rights violations committed by preceding dictatorships, while others still have amnesty laws that prevent -or at least hinder- the approval of such policies? We aim to demonstrate that, during democratization periods, the more legal the previous dictatorial repression, and the more direct judicial involvement in it, the more resistance there will be to apply policies of transitional justice. We will compare the Spanish case with those of Chile and Argentina. The establishment of democracy following a right-wing dictatorship responsible for the systematic violation of human rights forced all three countries to consider how best to confront this violent past. Once democracy has been consolidated, additional explanatory factors will account for the presence or absence of judicial accountability.

\section{KEYWORDS}

Dictatorships; Judicial System; Political Repression; Transitional Justice. 


\section{INTRODUCCIÓN}

En algunas investigaciones se afirma que distintos tipos de dictadura producen diversos procesos de democratización (Geddes 1999). También se han analizado de forma comparada las diversas políticas de justicia transicional (en adelante, JT) adoptadas por diferentes países (Aguilar 2008a; Barahona de Brito 1997; Nalepa 2010; Olsen, Payne y Reiter 2010). Por último, varios autores han estudiado el funcionamiento del sistema judicial en los regímenes autoritarios (Ginsburg y Tamir Moustafa 2008; Hilbink 2007; Pereira 2005). Sin embargo, no hemos encontrado investigaciones que hayan tratado de relacionar el tipo de prácticas represivas empleadas por las dictaduras, el grado de implicación del sistema judicial en ellas y las ulteriores políticas de JT.

En este artículo vamos a comparar el caso español con el chileno y el argentino. En los tres países existieron dictaduras de corte conservador, la violación de derechos humanos fue sistemática y ello les obligó a reflexionar sobre qué hacer con este pasado en sus respectivos procesos de democratización. No se va a llevar a cabo una comparación en términos de igualdad, sino que se procederá a una exposición más detallada de lo ocurrido en España, que es el caso menos investigado, y se realizarán comparaciones puntuales con lo acontecido en Chile y Argentina.

Existe una gran variación en cuanto a las medidas de JT adoptadas en estos tres países: Argentina fue pionera en cuanto a la celebración de juicios contra los responsables de violaciones de derechos y fue el país del Cono Sur en el que antes se anuló la Ley de amnistía que garantizaba su impunidad. En España el único proceso judicial que se ha celebrado 1 -el "caso Ruano" - no ha supuesto condena alguna ni ha contribuido al esclarecimiento de la verdad; tampoco — salvo en una única ocasión (Gil 2009:58)_ se han anulado las decenas de miles de sentencias de carácter político que tuvieron lugar durante la guerra civil y el franquismo, y ello a pesar de los numerosos recursos de revisión que se han presentado y de la evidente falta de garantías de que adolecieron; además, la ley de amnistía de 1977 sigue vigente y no existe debate político sobre la conveniencia de su anulación. Chile ocupa un lugar intermedio, pues, tras muchas resistencias iniciales, se han celebrado multitud de juicios y, aunque la ley de amnistía de 1978 también está en vigor, algunos actores sociales y políticos han llegado a proponer

Agradezco a Juan José del Águila, Cath Collins, Javier Chinchón, Jorge Correa, Alicia Gil, Pablo Gil, Catherine Hite, Mónica Lanero, Juan Antonio Mayoral, Conxita Mir, Manuel Ortiz, Joan Queralt y Patricia Tappatá la información que me han proporcionado. Asimismo, quiero expresar mi agradecimiento a los evaluadores anónimos que me han ayudado a mejorar este texto. Este artículo se enmarca en el Proyecto de Investigación "Represión dictatorial y sistemas judiciales. Los determinantes de la estabilidad autoritaria y de la justicia transicional". CSO2012-35664. Ministerio de Economía y Competitividad. Subprograma de proyectos de investigación fundamental no orientada (2013-2016).

${ }^{1}$ El intento fallido de proceso judicial iniciado por el juez Garzón se comentará más adelante. 
su anulación. Por último, mientras que Argentina y Chile han contado con comisiones de la verdad, no se ha establecido ninguna en España.

Nuestras hipótesis se refieren, fundamentalmente, a los procesos de transición democrática. Una vez que la democracia se ha consolidado, otros factores contribuyen a explicar por qué se han incrementado los juicios en Argentina, por qué se han empezado a celebrar en Chile y por qué las políticas de justicia y verdad apenas han experimentado avances en España. Las reformas institucionales, las iniciativas sociales, la voluntad política y judicial, y los avances en legislación internacional han resultado determinantes en algunos casos para cambiar las inercias heredadas de la transición.

\section{Debate teórico}

Los factores que más se han subrayado para explicar tanto la existencia de procesos judiciales contra los responsables de la represión autoritaria como la voluntad del Estado de esclarecer lo acontecido y reparar a las víctimas, son, fundamentalmente, la correlación de fuerzas existente entre los viejos y los nuevos gobernantes, las preferencias y cálculos estratégicos de las élites políticas, la legitimidad residual de la dictadura, la presión ejercida por las organizaciones de derechos humanos y la presencia de una memoria traumática fruto de la violencia política anterior (Aguilar 2008a; Barahona de Brito 2001; Elster 2004; 2006; Huntington 1991; Sikkink 2011; O’Donnell, Schmitter y Whitehead 1986). Nos proponemos demostrar que, siendo todo ello relevante, no se ha prestado suficiente atención a dos variables fundamentales, muy relacionadas entre sí: a) el tipo de represión predominante: clandestina u oficial; y b) el grado de implicación de la justicia — particularmente de la ordinaria — en la represión política a lo largo de la dictadura: directa o indirecta.

La variable dependiente de esta investigación no abarca todas las posibles medidas que se enmarcan dentro de las políticas de JT, sino que se centra en la existencia o no de juicios contra los principales responsables de violaciones de derechos, la vigencia o no de leyes de amnistía que impidan —o, al menos, dificulten — la celebración de dichos juicios una vez democratizado el régimen, y la creación de comisiones de la verdad que expongan públicamente el funcionamiento de la maquinaria represiva bajo la dictadura. Para el caso español, también se tendrá en cuenta la revisión de los juicios del franquismo.

Los casos de Argentina y Chile responden mucho más claramente a la categoría de "dictadura militar" que el caso español. Aunque Franco fuera militar y, sobre todo en sus primeros gobiernos, los militares tuvieran amplias competencias en el ámbito judicial y ocuparan carteras importantes, el franquismo no puede considerarse un régimen castrense. De hecho, no fueron solo los militares ni los cuerpos especiales de la policía - como en los otros dos casos - quienes llevaron a cabo la represión política, sino que el sistema judicial en su conjunto desempeñó un papel fundamental, pues no se limitó a mantener un 
silencio cómplice ante las violaciones de derechos, sino que fue una pieza fundamental de la maquinaria represiva, sobre todo a través de su participación directa en los consejos de guerra y en las jurisdicciones especiales que se crearon con tal propósito.

Según la primera hipótesis, en aquellos países en los que las víctimas son consecuencia de un sistema de represión ilegal diseñado desde el poder político-militar (como en Argentina), es más probable que los jueces se hayan mantenido en mayor medida al margen de la represión que allí donde ha prevalecido la represión legal (como en España). Es cierto que en los tres casos encontramos, aunque en distinta proporción, coexistencia de prácticas represivas legales e ilegales, pero mientras que en Argentina no se ejecutó ninguna condena a muerte por cuestiones políticas como consecuencia de una sentencia judicial, en España se ejecutaron decenas de miles.

Según la segunda hipótesis, cuanto mayor haya sido la implicación de la justicia ordinaria en la represión dictatorial —lo que tuvo lugar muy particularmente en España y, en menor grado, también en Chile-, mayor resistencia existirá a la hora de impulsar determinadas políticas de JT. Cuando las responsabilidades no solo recaen sobre la cúpula militar y ciertos cuerpos de la policía, sino que salpican al conjunto del sistema judicial, los jueces y fiscales tenderán a ser más reacios a cualquier revisión pública del pasado y mucho más a la aprobación de medidas punitivas contra los responsables de la represión. De hecho, los procesos judiciales han sido mucho más tardíos en Chile que en Argentina, mientras que en España no han tenido lugar. También observaremos mayor reticencia a derogar las leyes de amnistía que impiden o dificultan la celebración de dichos juicios: mientras que en Chile y en España esas leyes siguen en vigor, en Argentina se derogó tempranamente la ley de "autoamnistía" que aprobaron los militares antes de dejar el poder ${ }^{2} \mathrm{y}$, años después, también se declararon nulas e inconstitucionales las leyes de "obediencia debida" y "punto final" aprobadas bajo la presidencia de Menem para evitar que prosiguieran los juicios ${ }^{3}$.

En definitiva, cuanto más oficial y "legal" haya sido la represión de la oposición, más habrá estado implicada la judicatura en ella. Y, cuanto mayor haya sido el grado de colaboración del sistema judicial con la dictadura, más resistencia ofrecerá éste a que se someta a revisión judicial el pasado, 0 a que se esclarezca oficialmente toda la verdad sobre la represión mediante comisiones de la verdad, pues son la reputación y profesionalidad de todo el entramado jurídico las que podrían resultar perjudicadas. El mero hecho de revisar las causas judiciales del franquismo - muchas de ellas mal instruidas o carentes de las mínimas garantías judiciales-, podría poner en entredicho el rigor y la honorabilidad de los órganos judiciales a lo largo de muchos años, cuando el sistema judicial siempre ha sostenido que se mantuvo al margen de la represión y que en todo momento mantuvo su independencia.

\footnotetext{
${ }^{2}$ La ley n. ${ }^{\circ} 23.040$ derogó la ley n. ${ }^{\circ} 22.924$ de autoamnistía.

${ }^{3}$ Hay que destacar la influencia que tuvo la jurisprudencia de la Corte Interamericana de Derechos Humanos en la anulación de dichas leyes.
} 


\section{El tipo de REPRESIÓN PREDominante. OfICIAL O CLANDESTINA}

Muchos de los consejos de guerra y de las ejecuciones registradas en Chile y en España tras los respectivos golpes militares tuvieron un carácter dudosamente legal y coexistieron con asesinatos claramente ilegales auspiciados o permitidos por las autoridades militares (y, en el caso de España, también por las civiles). La particularidad del caso español es que el fracaso del golpe de Estado del 18 de julio de 1936 en aproximadamente la mitad del territorio desencadenó una guerra civil en la que ambos bandos cometieron multitud de ejecuciones extralegales. Hubieron de transcurrir varios meses para que se empezara a "judicializar" la represión (Gil 2010:273).

En España, la población reclusa al finalizar la guerra era de unas 270.000 personas; entre 1936 y 1942, casi medio millón de prisioneros políticos pasaron por los más de 100 campos de concentración que se crearon y varias decenas de miles de españoles fueron sometidos a consejos de guerra (Rodrigo 2003 y Gil 2010). Por lo que se refiere a las víctimas mortales, según las últimas estimaciones, la represión franquista causó unas 130.000 muertes (unas 50.000 de ellas después de la guerra civil; véase Espinosa 2010:77-8) y la republicana unas 50.000. Aunque todavía no existen cifras oficiales ni consensuadas por los investigadores para el período posterior, según algunas fuentes entre 1958 y 1975 la jurisdicción militar mandó ejecutar 13 penas de muerte por consejos de guerra -4 por garrote vil y 9 fusilamientos (VV. AA 1976:1014).

En Chile, la "caravana de la muerte violó de forma deliberada la propia legalidad del régimen" (Pereira 2005:101). En los meses posteriores al golpe militar, "el número de personas ejecutadas de forma sumaria por el ejército o la policía (carabineros) parece sobrepasar de forma clara aquellos sometidos a algún tipo de tratamiento judicial. Los procesados fueron juzgados en tribunales militares compuestos exclusivamente por oficiales del ejército que actuaron como si el país estuviera en guerra" (Pereira 2005:25)4. A lo largo de los tres primeros años, "unos seis mil chilenos fueron juzgados por dichos tribunales [...]. Aproximadamente doscientos fueron sentenciados a muerte y ejecutados" (Constable y Valenzuela 1991:118).

Tanto en España como en Chile se avanzó hacia la "judicialización" - siempre imperfecta- de la represión, pero, mientras que en el primer caso los consejos de guerra siguieron dictando penas de muerte, aunque a un ritmo cada vez menor, en el segundo dejaron de aplicar la pena capital. Con el paso del tiempo, la represión extralegal chilena - protagonizada, en buena medida, por la policía política y unidad de inteligencia denominada Dirección de Inteligencia Nacional (DINA) - acabó siendo la única responsable de las muertes que siguieron teniendo lugar. Es cierto que con la disolución de la DINA

\footnotetext{
${ }^{4}$ En muy pocos casos jueces civiles formaron parte de los consejos de guerra, pero no se tiene constancia de que ninguno de ellos votara a favor de la imposición de la pena de muerte.
} 
en 1977 y su sustitución por la CNI la represión se atenuó considerablemente, pero también lo es que experimentó algunos repuntes, como a partir de 1980 (Informe CONADEP (1997:978). Al final, entre 3.000 y 5.000 personas desaparecieron o fueron asesinadas (entre 23,07 y 34,62 por cada 100.000 habitantes), unas 60.000 fueron encarceladas por motivos políticos (461,54 por cada 100.000 habitantes; véase Pereira 2005:21) y varias decenas de miles fueron torturadas.

Argentina es un caso distinto: aunque la pena de muerte se restableció durante la dictadura, ni los consejos de guerra militares, ni los tribunales ordinarios llegaron a ejecutar ninguna pena capital. Todas las muertes y desapariciones que tuvieron lugar en este país fueron resultado de la maquinaria de represión extralegal y clandestina puesta en marcha por las juntas militares, llegando a constituir uno de los casos más puros de "terrorismo de Estado". Las víctimas eran secuestradas por las fuerzas de seguridad, llevadas a centros clandestinos de detención, torturadas y, en muchos casos, asesinadas ocultando posteriormente sus cadáveres. La cifra de muertos y desaparecidos oscila entre 20.000 y 30.000 (entre 62,5 y 93,75 por cada 100.000 habitantes), unas 30.000 personas fueron encarceladas por motivos políticos $(93,75$ por cada 100.000 habitantes; véase Pereira 2005:21) y varias decenas de miles fueron torturadas.

Por último, mientras que en Chile unas 6000 personas fueron juzgadas en consejos de guerra por delitos políticos, solo unas 350 lo fueron en Argentina; el porcentaje es de 46,1 de cada 100.000 personas en Chile y de tan solo 1,09 en Argentina. La justicia política fue mucho más violenta en España que en Chile, tanto en términos absolutos como relativos (Pereira 2005:21 y 180). Por lo que se refiere a las personas juzgadas en consejos de guerra frente a las víctimas de ejecuciones extrajudiciales, la ratio es de 1,5 por cada 1 en Chile y de 1 por cada 71 en Argentina (Pererira 2005:21).

\section{LA IMPLICACIÓN DEL SISTEMA JUDICIAL EN LA REPRESIÓN}

La intensa represión política practicada durante la guerra civil española por ambos bandos, y la llevada a cabo en la posguerra por los franquistas, no habría sido posible sin la implicación de los profesionales de la justicia. Aunque la mayoría de la represión, sobre todo la que se produjo durante la guerra y la posguerra, tuvo lugar en el ámbito de la justicia militar, es fundamental tener en cuenta la participación de la justicia ordinaria en la implacable maquinaria represiva a lo largo de toda la dictadura.

a) La justicia militar franquista, principal —aunque no única - protagonista de la represión bélica y posbélica, se hubo de nutrir, dada la ingente cantidad de procesos judiciales a que tuvo de hacer frente, fundamentalmente entre 1936 y 1944, de personal procedente de la justicia ordinaria: "numerosos jueces, fiscales y magistrados participaron activamente en la jurisdicción militar como jueces instructores, fiscales o ponentes de los consejos de guerra" (Lanero 1996:335-6). Estos profesionales de la justicia 
aceptaron militarizarse temporalmente ${ }^{5}$, en muchos casos de forma voluntaria ${ }^{6}$, lo que significó que formaron parte de los tribunales militares que, hasta mediados de los años cuarenta, se calcula que ejecutaron unas 50.000 penas de muerte, aunque las que dictaron y luego indultaron fueron muchas más. Desde 1941, con motivo de la reducción del número de juicios, se empezó a desmovilizar al personal judicial militarizado y a devolverlo a la justicia ordinaria. El personal "jurídico militar" siguió participando en los consejos de guerra hasta el final de la dictadura (e incluso, posiblemente, después, ya que el Código de Justicia Militar de 1945 se mantuvo vigente hasta 1980) a través de la figura del 'vocal ponente', cuya presencia era obligada'.

La mayoría de las sentencias se dictaron en consejos de guerra mediante procedimiento sumarísimo ${ }^{8}$, lo que limitaba considerablemente las oportunidades de defensa de los acusados. En ocasiones el veredicto estaba decidido de antemano $y$, en muchos casos, ni siquiera se respetaban las formalidades mínimas de rigor, incumpliéndose la ya de por sí represiva legislación vigente. En el caso de los procedimientos sumarísimos no solo era obligatorio que el abogado defensor fuera un militar $^{9}$, sino que, además, debía ser el de menor graduación del consejo de guerra. Al abogado, debido al procedimiento sumarísimo, apenas se le proporcionaba tiempo para preparar su defensa y, dada su posición de subordinación en la estructura militar, apenas tenía posibilidades reales de defender al acusado.

${ }^{5} \mathrm{~A}$ partir de finales de 1936, se produjo una "incorporación masiva al Cuerpo Jurídico Militar Honorario no solo de personal judicial, sino de letrados civiles y de los licenciados en Derecho llamados a filas". Con posterioridad, "se abre la escala honoríica no solo a jueces y fiscales, sino [...] a todos los profesionales jurídicos y a los licenciados en derecho" (Lanero 1996: 362). Esta insólita implicación de todas las categorías profesionales relacionadas con el mundo jurídico constituye una prueba irrefutable de su participación en la represión franquista.

${ }^{6}$ No solo se trató de la "asimilación obligada" para "jueces, fiscales y aspirantes a ambas carreras", sino que también se "abre las puertas a la militarización voluntaria de magistrados, jueces y fiscales que abandonan el servicio de Juzgado o la Audiencia por el desempeño de funciones jurídico-militares en Consejos de Guerra y asesorías jurídicas de Auditorías y ministerios militares" (Lanero 1996:363).

${ }^{7}$ De hecho, era el único miembro del consejo que debía ser licenciado en Derecho y era el encargado de redactar el proyecto de sentencia, de ahí la gran trascendencia que tuvo en la represión (agradezco a Juan José del Águila esta información). Por otro lado, en los consejos de guerra posteriores a la gran desmovilización de mediados de los cuarenta, se observa la participación de juristas del ámbito universitario, ya que podían compatibilizar sus tareas docentes con el trabajo en el Cuerpo Jurídico (agradezco este dato a Pablo Gil; Juan José del Águila (2012) ha demostrado también la participación en la jurisdicción de guerra franquista de varios célebres catedráticos de derecho, que han omitido ese dato en sus biografías).

${ }^{8}$ Dichos procedimientos son propios de un estado de guerra, que, de hecho, se mantuvo declarado en España hasta 1948. A pesar de todo, con posterioridad a esa fecha continuaron aprobando leyes que siguieron permitiendo a la jurisdicción militar hacer uso de los procedimientos sumarios para ciertos delitos.

${ }^{9}$ En todo caso, según Juan José del Águila (en comunicación personal), lo más habitual fue excluir a los abogados civiles de los consejos de guerra, aunque no fueran sumarios, al menos hasta 1963. Los abogados civiles solo pudieron defender a los prisioneros políticos una vez que la justicia ordinaria recuperó su jurisdicción sobre los delitos políticos, fundamentalmente mediante la creación del Tribunal de Orden Público, esto es, a partir de 1963. 
También en Chile y en Argentina la justicia militar celebró consejos de guerra en época de paz, proclamando, asimismo, el Estado de guerra o el Estado de excepción para incrementar su capacidad represiva y limitar los derechos de los ciudadanos ${ }^{10}$. En Chile los jueces civiles solo participaron de forma excepcional en los consejos de guerra, los fiscales eran siempre militares (Pereira 2005:24) y los abogados de los encausados podían ser civiles.

Es evidente que la mayor parte del sistema judicial chileno fue cómplice de la represión dictatorial. Pero, por un lado, no participó en la mayoría de los consejos de guerra que dictaron y ejecutaron penas de muerte y, por otro, hay constancia de que algunos jueces trataron de mantenerse neutrales ante el poder político -lo que, en no pocas ocasiones, les ocasionó graves problemas-y de que algunos abogados hicieron lo imposible por defender a sus clientes ante los consejos de guerra (Constable y Valenzuela 1991:115-139) ${ }^{11}$.

En Argentina, a pesar de las complicidades de una parte importante del sistema judicial, la estrategia represiva fue básicamente extrajudicial ${ }^{12}$; también es el caso en el que encontramos "el menor grado de cooperación e integración cívico-militar en el ámbito judicial". Por otro lado, "en Argentina había más oposición en la judicatura a las nociones militares de seguridad nacional que en Chile". En aquel país los consejos de guerra apenas se usaron para perseguir judicialmente a los disidentes políticos. Y, a diferencia de lo ocurrido en los otros casos, "los jueces y los abogados también estuvieron en el punto de mira del régimen: más de cien abogados de presos políticos desaparecieron entre 1976 y 1983" (Pereira 2005:13, 119, 26).

b) La justicia ordinaria española también participó en una serie de jurisdicciones especiales que se crearon para la represión política. Destaca su implicación en la jurisdicción de Responsabilidades Políticas ${ }^{13}$, pero también colaboró en el Tribunal Especial

${ }^{10} \mathrm{En}$ Chile "el derecho de amparo fue revocado durante los estados de sitio" (Constable y Valenzuela 1991:137). Los consejos de guerra se mantuvieron durante los cinco primeros años posteriores al golpe militar; entre 1978 y 1989 se siguieron celebrando consejos militares, pero ya de carácter ordinario (Pereira 2005:4 y 25). En Argentina, el Estado de sitio estuvo declarado hasta octubre de 1983 y se celebraron consejos de guerra sumarios, y secretos, en los que no se permitía la participación de abogados defensores civiles, pero estos tribunales tuvieron mucha menos actividad que en los otros dos países (Pereira 2005:133). Véanse también Hilbink (2007) y Barros (2002; 2008).

${ }^{11}$ Las biografías de los principales abogados antifranquistas han sido recogidas en Gómez Alén y Vega García (2010).

12 "El régimen argentino destaca por su casi completo desprecio de las convenciones legales. Unas 350 personas fueron condenadas en tribunales militares, pero su principal respuesta ante la oposición política fue una guerra sin cuartel [...] llevada a cabo prácticamente sin restricciones judiciales" (Pereira 2005: 26).

${ }^{13}$ La Ley de Responsabilidades Políticas de 9 de febrero de 1939 tuvo efectos retroactivos hasta octubre de 1934. Las sanciones eran, básicamente, de tres tipos: inhabilitación, destierro y sanción económica. Unas 300.000 personas fueron sometidas a expediente. El $20 \%$ de los magistrados y el $3 \%$ de los 
para la represión de la Masonería y el Comunismo, la jurisdicción de Vagos y Maleantes ${ }^{14}$, las Fiscalías de Tasas y la Jurisdicción Laboral (Lanero 1996:343, 374). En varios de estos casos, como en los consejos de guerra, se establecieron "tribunales mixtos", formados por militares (que normalmente eran mayoría y solían ocupar los puestos más relevantes), miembros de la jurisdicción ordinaria y militantes del partido único (FET y de las JONS) (Álvaro Dueñas 1990). La extraordinaria expansión de la jurisdicción militar -invadiendo multitud de competencias previamente reservadas a la jurisdicción ordinaria y teniendo clara preeminencia sobre esta en caso de conflicto de competencias- y, sobre todo, la proliferación de jurisdicciones especiales dedicadas a la represión, no tienen parangón en los casos chileno y argentino.

c) La denominada "Causa General" fue creada por Decreto de 26 de abril de 1940. En ella se atribuía al Ministerio Fiscal, subordinado al Ministerio de Justicia, la tarea de investigar la actividad supuestamente criminal de los simpatizantes del bando vencido en la guerra civil. Esta información fue recopilada por los fiscales de la justicia ordinaria hasta los años sesenta y condujo a la apertura de decenas de miles de procesos judiciales. No existe nada equivalente en los países del Cono Sur.

d) Hasta ahora hemos centrado nuestra atención en la primera etapa de la dictadura española, que fue la más represiva, pero el franquismo no dejó de perseguir a los disidentes hasta el final. Con el paso del tiempo, la justicia ordinaria fue la que adquirió un mayor protagonismo en esta tarea; destaca su participación exclusiva en el Tribunal de Orden Público (TOP), en el que jueces y magistrados asumieron, a partir de 1963 y hasta finales de 1976, con carácter muchas veces voluntario, el protagonismo en la represión ideológica y política, salvo en el caso de los delitos de terrorismo, de los que se seguía encargando la jurisdicción militar ${ }^{15}$.

En Argentina y Chile no se creó ningún tribunal civil destinado a la represión. Resulta asombroso que el TOP fuera capaz, en los últimos años del franquismo, de dictar tantas sentencias condenatorias, y de tal dureza, por acciones que, en su mayoría, suponían el ejercicio de los derechos políticos más elementales en democracia.

jueces "se dedicó a la exigencia de responsabilidades políticas" y la pertenencia a estos organismos era voluntaria (Lanero 1996:373).

${ }^{14}$ La Ley de Vagos y Maleantes, data de 1933. Fue modificada por el franquismo en 1954 para incluir la persecución de los homosexuales. En 1970 fue derogada y sustituida por la Ley sobre Peligrosidad y Rehabilitación Social.

${ }^{15}$ La principal fuente para el estudio del TOP es Del Águila (2001). Para evitar la lentitud generada por la cantidad de casos acumulados en este tribunal especial, además de ampliarse a finales de 1971 las plazas de magistrados y de crearse un segundo juzgado, se impuso "a los jueces de instrucción y a los fiscales de toda España la obligación de practicar las primeras diligencias, convirtiéndoles en servidores del Juzgado de Orden Público" (Justicia Democrática 1978:46). De esta forma, se ampliaba aún más la implicación de la justicia ordinaria en la maquinaria represiva del franquismo. 
e) La justicia ordinaria española, incluso cuando actuó fuera del ámbito de las jurisdicciones especiales, colaboró con la dictadura mediante el control social que ejerció sobre la población y la aplicación, en sus sentencias, de la ideología franquista (Ortiz 1996; Mir 2000). También se ha documentado la estrecha colaboración de la justicia con la policía política del régimen, la Brigada Político-Social, y su constante inhibición ante las denuncias por casos de tortura ${ }^{16}$.

Las únicas cifras disponibles sobre las penas de muerte ejecutadas por la justicia ordinaria, por delitos de tipo no político, se refieren al período 1947 a 1975 y ascienden a $41^{17}$. Entre 1936 y 1946 no existen datos oficiales sobre el número de ejecuciones dictadas por la justicia ordinaria ${ }^{18}$, pero lo cierto es que la legislación vigente le permitía dictar sentencias de muerte en varios supuestos, incluso, durante algunos años, por motivaciones de tipo político.

La justicia ordinaria no ejecutó ninguna pena de muerte ni en Chile ni en Argentina, pero hay constancia de su inhibición en varios casos en los que los abogados de los detenidos solicitaron el recurso de amparo (Pereira 2005:23 y 54). Según otros autores, los jueces "se mostraron especialmente reacios a desafiar a la DINA y a otras agencias de policía secreta, las cuales casi siempre negaron cualquier detención y rechazaron ofrecer información aduciendo cuestiones de seguridad nacional" (Constable y Valenzuela 1991:116 y 123). Con todo, a pesar de las críticas que se vierten en el denominado Informe Rettig sobre el funcionamiento del sistema judicial bajo la dictadura chilena, también se reconoce que "a finales de los años 70 se produjeron las primeras investigaciones exhaustivas" y que, "a pesar de las dificultades en materia de apoyo policial, Ministros en Visita y jueces de primera instancia lograron acreditar la existencia de delitos y la eventual participación de uniformados en los mismos"; si bien, por ello mismo, hubieron de declararse incompetentes y, una vez en manos de la justicia militar, las causas no prosperaron (Informe Rettig: Capítulo IV, apartado A).

El informe CONADEP de Argentina es igualmente crítico con la inhibición y el silencio cómplice de los jueces. Pero también dice que hubo jueces "que, dentro de las tremendas presiones sufridas por la situación reinante, cumplieron su función con la dignidad y el decoro que se esperaba de ellos". Y que la "asistencia jurídica" se vio muy perjudicada por el "extrañamiento o muerte de los abogados defensores" (1997:392). En general, en Argentina "los tribunales estuvieron mayoritariamente al margen del sistema repre-

\footnotetext{
${ }^{16}$ Esta Brigada tiene su origen en una Ley del 8 de marzo de 1941 y se mantiene hasta su derogación el 9 de diciembre de 1978 (tres años después de muerto Franco). Los jueces y fiscales garantizaron su impunidad, pues "era normal en el Tribunal de Orden Público 'impedir preguntas directas' sobre malos tratos policiales". Asimismo, "las denuncias contra la Brigada Social eran desoídas, sin exigir ninguna clase de responsabilidades a los jefes e inspectores responsables" (Jiménez Villarejo 2011:213-215). Véase también Justicia Democrática (1978:23, 65, 244-5).

${ }^{17}$ VV.AA (1976:1014).

${ }^{18}$ Resulta revelador que la Colección de Jurisprudencia Criminal dejara de publicarse entre 1936 y 1946 (Serrano 1993), coincidiendo con la guerra civil y los años más duros de la represión dictatorial.
} 
sivo, excepto cuando denegaron el habeas corpus dando cobertura al estado de terror" (Pereira 2005:4).

Lo anterior demuestra la existencia, al menos en ciertos sectores de la profesión legal, de una mayor beligerancia con la dictadura que en España. En nuestro país la única $-\mathrm{y}$ tardía - resistencia judicial a la dictadura vino de la mano de Justicia Democrática ${ }^{19}$.

f) El Tribunal Supremo español no se separó de la doctrina franquista en la interpretación de la ley y defendió hasta el final la ideología del régimen en sus sentencias (Bastida 1986). Además, el máximo órgano judicial contribuyó "a la subordinación de la justicia ordinaria al fallar las cuestiones de competencia que se suscitan entre Tribunales ordinarios y militares con un criterio indefectiblemente favorable a la jurisdicción castrense" (Lanero 1996:325-6) ${ }^{20}$.

En el caso chileno, los miembros del Tribunal Supremo simpatizaron con el golpe de Pinochet desde el principio, renunciaron a controlar las acciones del Ejecutivo y a investigar las violaciones de derechos. De hecho, entre 1973 y 1983, este tribunal "solo aceptó 10 de las 5400 peticiones de habeas corpus enviadas por la Vicaría" (Constable y Valenzuela 1991:122). Es cierto que "unos pocos jueces de dicho tribunal se arriesgaron, esporádicamente, a mostrar, con delicadeza, opiniones discrepantes sobre la represión y la manipulación de la ley, pero la mayoría se limitó a someterse a los deseos del régimen" (Constable y Valenzuela 1991:130). Por último, de forma similar a lo ocurrido en España, "el Tribunal Supremo chileno rechazó revisar cualquier veredicto de los tribunales militares" (Pereira 2005:4).

En el caso argentino, la desconfianza de los militares hacia la Corte Suprema fue, como veremos, mucho mayor.

Para analizar la implicación del sistema judicial en la represión es importante conocer su grado de independencia respecto al Ejecutivo. Para ello hay que saber si las dictaduras depuraron la judicatura al tomar el poder y si crearon mecanismos para sojuzgar a los jueces y limitar el control que podían ejercer sobre el poder político.

En el caso español, hubo una purga de todas las profesiones que, si bien en menor medida, también afectó a la jurídica: "[l]a separación del servicio alcanzó al $6 \%$ de la carrera judicial, y al $12 \%$ de la carrera fiscal" (Lanero 1996:379). Ello le sirvió al franquismo para asegurarse la lealtad de jueces, magistrados y fiscales.

\footnotetext{
${ }^{19}$ Solo esta organización, creada en 1971, alzó su voz contra el sometimiento del sistema judicial a la dictadura y el respaldo que recibió fue escaso. De hecho, "la inmensa mayoría de los jueces y fiscales se mantuvieron fieles a la legalidad dictatorial y ni un solo alto cargo de la dictadura se enroló o tan siquiera simpatizó con Justicia Democrática" (Sartorius y Sabio 2007:517).

${ }^{20}$ Resulta llamativo que en el enlace denominado "Historia del Tribunal Supremo" de la página web oficial de dicho órgano no aparezca mención alguna a la guerra civil ni a la dictadura, a pesar de lo importantes que fueron estos acontecimientos para la historia de dicho órgano (de 1931 se pasa a 1978). Puede consultarse en la siguiente dirección electrónica: http://www.poderjudicial.es/cgpj/es/Poder_Judicial/Tribunal_Supremo/ Informacion_institucional/Historia_del_TS
} 
Durante los primeros años, el control en el acceso a estas profesiones también se llevó a cabo mediante la reserva de plazas: "[e]n las oposiciones a la judicatura del año 1941, de 130 plazas convocadas, 26 eran de turno libre y 26 para cada uno de los siguientes grupos: a) caballeros mutilados; b) alféreces provisionales; c) excombatientes; d) excautivos y huérfanos de la guerra" (Sartorius y Sabio 2007:490). Además, al asumir su cargo los jueces debían jurar "incondicional adhesión al Caudillo de España", lo que no parecía dejar mucho margen a la imparcialidad ${ }^{21}$.

El régimen franquista también creó un instrumento fundamental de selección por criterios ideológicos y de adoctrinamiento político posterior, la Escuela Judicial, dependiente del Ministerio de Justicia. El paso por ella durante año y medio de todos los jueces, magistrados y fiscales contribuye a explicar su conservadurismo, pues, además de las materias estrictamente jurídicas, se les impartía formación "moral" y "religiosa". También se pretendía con dicha escuela "inculcar a los alumnos el espíritu de cuerpo y la obediencia debida a sus superiores jerárquicos". Incluso el Ministro de Justicia reconoció que su propósito había sido crear "una milicia de la Justicia [...] siempre dispuesta a seguir [...] las consignas del Caudillo" (Lanero 1996:269 y 272).

Otros mecanismos institucionales usados por el franquismo para limitar la independencia judicial fueron: "reclutamientos, nombramientos, sanciones disciplinarias, promociones y transferencias" (Magalhães, Guarnieri y Kaminis 2006:146-7). De hecho, la asociación clandestina Justicia Democrática nace, fundamentalmente, para expresar su descontento por "[e]l férreo control ejercido por el ejecutivo sobre la carrera judicial a través del nombramiento de los más importantes cargos" y "[l]a profusión con que se utilizaba la figura de 'las excedencias especiales', que posibilitan el paso de un gran número de funcionarios judiciales y fiscales a la política" (Fernández 1995:69).

Varios jueces y fiscales ocuparon cargos importantes en el Ministerio de Justicia y en otros órganos de la administración, ocurriendo que la mayoría de ellos tenían "un pasado de funciones en jurisdicciones especiales"; de hecho, "casi todos los funcionarios con cargos ministeriales [habían] pasado por la jurisdicción militar" (Lanero 1996:378). Según esta misma autora, haber participado en tareas represivas era un buen medio para medrar en la administración y en la política, pues los que habían formado parte de consejos de guerra, y otras jurisdicciones especiales de carácter represivo, tendían a ser recompensados con altos cargos en la administración. Esto, como se verá después, también ocurrió en democracia con muchos de los jueces y fiscales que habían formado parte del TOP.

En Chile se permitió más independencia al sistema judicial porque la sintonía ideológica estaba clara desde el principio. De hecho, la profesión jurídica había mostrado profundas discrepancias ideológicas durante la presidencia de Allende. Pinochet, mediante una aproxi-

\footnotetext{
${ }^{21}$ Este juramento se empezó a realizar a partir de 1938 "en el ingreso en las carreras judicial y fiscal y en cada nueva toma de posesión" (Lanero 1996:273). Todos los jueces, magistrados y fiscales que hereda la democracia habían llevado a cabo dicho juramento.
} 
mación respetuosa a los jueces, trató de asegurarse su colaboración y aquiescencia (Pereira 2005:23; Constable y Valenzuela 1991:117). Ello explica que el Ejecutivo no depurara el Tribunal Supremo y que en el resto del sistema judicial las purgas fueran muy limitadas ${ }^{22}$.

En Argentina, sin embargo, "el mismo día del golpe de estado, se cambió la composición del Poder Judicial a nivel de la Corte Suprema, del Procurador General de la Nación y de los Tribunales Superiores de Provincia [...]. Todo Juez, para ser designado o confirmado, debió previamente jurar fidelidad a las Actas y objetivos del 'Proceso' liderado por la Junta Militar" (Informe CONADEP 1997:391). A pesar de esa depuración inicial, la colaboración entre jueces y militares fue mucho menor que en los otros casos (Pereira 2005).

La irrevocabilidad de los cargos judiciales fue respetada por el poder político en el caso chileno, ya que se fió de los controles ejercidos por el Tribunal Supremo sobre el resto de la profesión judicial, pero no en el argentino.

\section{AMNISTÍAS, JUICIOS Y COMISIONES DE LA VERDAD}

Para entender las medidas de JT que, finalmente, se adoptaron, es necesario conocer el estado del sistema judicial al finalizar las dictaduras. En España, "el mundo jurídico era el que se había mostrado más correoso a la evolución de los tiempos" (Sartorius y Sabio 2007:485). Según otro autor: "Los jueces que hacían pública manifestación de su ideología franquista eran escasos, pero ocupaban los escalafones más altos de la cúpula judicial", y no pocos se negaban a aplicar la legislación democrática (Gor 1996:222).

Múltiples pruebas avalan el conservadurismo del sistema judicial en la transición española y su resistencia a los cambios (Ruiz 1985). Los testimonios del primer ministro de justicia socialista (1982-1988), Fernando Ledesma, y de su jefa de gabinete (19821985), María Teresa Fernández de la Vega, resultan reveladores. Ambos insisten en la necesidad imperiosa de democratizar elámbito de la justicia y en los "ataques", "presiones" y "tensiones" que tuvieron que soportar cuando intentaron reformarlo. También aluden a su fuerte sentido corporativo y al gran poder que ostentaban. Asimismo, insisten en la necesidad de evitar un enfrentamiento frontal con el sistema judicial dada su gran capacidad para ejercer presión sobre el sistema y al hecho de que era imprescindible contar con él para el correcto funcionamiento de la todavía frágil democracia. Mientras que el ex-ministro sostiene que "un poder judicial puede acelerar 0 , por el contrario, retrasar, las transformaciones de la sociedad, puede facilitarlas o dificultarlas, puede

\footnotetext{
${ }^{22}$ De hecho, "El Tribunal Supremo aceptó, de forma voluntaria, depurar a aquellos de sus miembros sospechosos de simpatizar con Allende [...], y obstaculizó los ascensos profesionales de aquellos jueces que se pensaban que eran demasiado izquierdistas" (Huneeus 2010:103).
} 
favorecer la modernización de un país o, por el contrario, puede entorpecerla", la ex jefa de Gabinete insiste en que la justicia iba a ser la responsable de la "interpretación y aplicación" de las reformas y que, por lo tanto, era un "elemento imprescindible para la estabilidad y el cambio político" (Iglesias 2003:990 y 1005).

La constancia de que el estamento judicial había estado profundamente implicado en la represión franquista, del conservadurismo ideológico en sus más altas esferas, de la irritación con la que recibía cualquier intento de reforma y, sin embargo, de su protagonismo absoluto a la hora de aplicar la nueva legislación democrática, contribuye a explicar que los gobiernos no se atrevieran ni siquiera a pensar en la posibilidad de someter a escrutinio público (mediante una comisión de la verdad), y mucho menos aún a revisión judicial, el funcionamiento de la maquinaria represiva bajo el franquismo ${ }^{23}$. Los poderes democráticos, al final, se conformaron con tres reformas institucionales: a) la creación del Tribunal Constitucional, órgano independiente que actúa como mecanismo de control de las sentencias judiciales; se trataba de "fiscalizar una institución que entró en el sistema democrático sin apenas depuración" (Benito 2009:177); b) la reforma de la Ley Orgánica 6/1985 del Poder Judicial, por la que la elección del Consejo General del Poder Judicial deja de estar en manos de jueces y magistrados y pasa al Parlamento; y c) la "jubilación anticipada de un tercio del escalafón judicial con el fin de separar a las viejas figuras del régimen de las altas esferas judiciales" (Benito 2009:175).

A pesar de la importancia que tuvieron estas reformas, la depuración fue limitada y tardía. El estamento judicial siguió siendo predominantemente conservador ${ }^{24}$ y nunca se ha denunciado públicamente su colaboración con la represión, ni el trasvase de muchos de sus miembros más conservadores -incluso de los jueces y fiscales del TOP- a organismos como el Tribunal Supremo o la Audiencia Nacional (Bastida 1986:13; Gor 1996: 222; Sartorius y Sabio 2007: 494).

La falta de una depuración exhaustiva se vio agravada por la endogamia del sistema judicial ${ }^{25}$, sus mecanismos de socialización y reclutamiento internos, y su arraigado

\footnotetext{
${ }^{23}$ La Sala Quinta, o de lo Militar, del Tribunal Supremo es la encargada de pronunciarse sobre la revisión y, en su caso, anulación, de las sentencias de los consejos de guerra que tuvieron lugar durante la contienda y la dictadura. Dicha Sala se creó en 1987 tras la disolución del Consejo Supremo de Justicia Militar, órgano creado en 1939 y que desempeñó un papel fundamental en la represión judicial. La mitad de los miembros de dicha Sala, que tiene reputación de ser la más conservadora del Tribunal Supremo, proceden del cuerpo Jurídico Militar. Ya se ha expuesto que todos los consejos de guerra que se celebraron bajo la dictadura contaban con una persona perteneciente a dicho cuerpo. El conservadurismo de Ángel Calderón Cerezo, presidente de dicha Sala en el momento de redactarse este artículo, es bien conocido; de hecho, siempre ha votado en contra de la revisión de sentencias del franquismo. Diario El País, 2/06/2011.

${ }^{24} Y$ así lo perciben los españoles incluso en nuestros días: un $45,2 \%$ piensa que los jueces son fundamentalmente conservadores, frente a tan solo un $12 \%$ que opina que son progresistas (CIS 2861; febrero 2011).

${ }^{25}$ "[E] grado de auto reclutamiento específico [jueces hijos de jueces] era mucho más alto en España que en Francia o Italia" (Toharia 1975:65).
} 
espíritu de cuerpo. Un sistema de estas características difícilmente iba a consentir medidas de justicia o verdad que pudieran poner en entredicho su honorabilidad, no sólo bajo la dictadura sino incluso con posterioridad, pues es conocida la tolerancia de no pocos jueces con la brutalidad de las fuerzas de orden público y la violencia de extrema derecha registrada durante la transición (Gor 1996:223).

En Argentina, Alfonsín consiguió que el Tribunal Supremo, designado por la Junta Militar, dimitiera voluntariamente al hacer pública su intención de depurarlo. También hubo discusión sobre si los jueces debían mantenerse en sus puestos. Al final, solo fueron apartados unos pocos. Con todo, "la depuración de la Corte Suprema y la modificación de la jurisdicción militar" serían determinantes para explicar la renuencia de los jueces a detener los procesos judiciales tras las leyes de punto final y obediencia debida y los indultos de Menem (Barahona de Brito 1997:137).

En Chile no se depuró el Tribunal Supremo. Su conservadurismo durante la transición y su resistencia inicial a revisar el pasado son conocidos. Algunos asesores del Presidente Aylwin "pensaron que los jueces civiles chilenos, especialmente los del Tribunal Supremo, habían sido cómplices de las violaciones de derechos humanos bajo el régimen de Pinochet, lo que era inaceptable". Sin embargo, aunque los líderes políticos llegaran a la conclusión de que "no podían esperar, siendo realistas, limpiar la judicatura de todos los que habían colaborado con la represión y contribuido a disimularla", lo cierto es que "sí podían reformar los procedimientos y la arquitectura de la misma, que es lo que finalmente hicieron" (Pereira 2005:170) ${ }^{26}$.

En España, la ley de amnistía de 1977 había sido la demanda más solicitada por la oposición al franquismo. Cuando murió Franco arreciaron las presiones y comenzaron a aprobarse medidas de gracia parciales. El precedente más significativo es el Real Decreto-Ley de Amnistía de julio de 1976, el cual incluía delitos de naturaleza política "en tanto no hubieran puesto en peligro o lesionado la vida o la integridad de las personas". Esta cláusula fue interpretada en sentido muy restrictivo por los jueces, por lo que las manifestaciones a favor de la amnistía continuaron celebrándose.

La amnistía del 15 de octubre de 1977 fue la primera ley aprobada por el recién estrenado Parlamento democrático. Los primeros borradores partieron de los partidos de la oposición y no contenían ninguna cláusula que amnistiara a las autoridades responsables de haber cometido violaciones de derechos durante el franquismo, sino la excarcelación de los presos políticos (la mayoría de los pocos que aún permanecían en prisión habían sido sentenciados por casos de terrorismo), la anulación de sus antecedentes penales, la reintegración en sus trabajos y el derecho a cobrar pensión si se encontraran en edad de jubilación. Sin embargo, la Unión de Centro Democrático (UCD) consiguió incluir dos cláusulas que también amnistiaban a las autoridades que hubieran cometido violaciones de derechos (Aguilar 2008a).

${ }^{26}$ Sobre estas reformas, véase Collins (2010). 
La ley que resultaría finalmente aprobada, casi por unanimidad, contendría estas medidas que, con posterioridad, han sido aducidas para impedir la celebración de jui$\operatorname{cios}^{27}$. A pesar de ello, esta ley también fue sumamente generosa con terroristas que tenían delitos de sangre recientes, algunos de ellos cometidos, precisamente, contra las fuerzas de seguridad del Estado. La capacidad del Ejército para desestabilizar el sistema democrático fue, al principio de la transición, importante, y ello contribuye a explicar que la impunidad de los represores no fuera cuestionada en esos momentos.

En Chile, la ley de amnistía de 1978 fue aprobada, igual que la argentina y a diferencia de la española, por la propia dictadura, pero cubre únicamente su etapa más represiva: 1973-1978. Durante sus primeros quince años de vigencia, se aplicó, salvo excepciones, sin realizar investigación alguna. Sin embargo, la propia norma contempla que "el juez necesita llevar a cabo una investigación previa a la concesión de la amnistía", para establecer el tipo de participación de los individuos juzgados. A pesar de ello, la Corte Suprema decidió interpretar el decreto de otra forma, concediendo la amnistía sin investigar, mientras que el juez Carlos Cerda optó por llevar a cabo todas las pesquisas necesarias antes de conceder la amnistía. En los años noventa, esta estrategia acabó prevaleciendo: "la amnistía solo podía aplicarse [...] si se llevaba a cabo una investigación y si, a través de esta, se confirmaba que se había producido un homicidio y que la participación de los responsables podía ser establecida" (Lira 2006:86). Es lo que vino a ser conocido como "doctrina Aylwin"28.

${ }^{27}$ La única vez que se celebró un juicio fue en el "caso Ruano". El él se demuestra que, de haberse iniciado antes las causas judiciales, se habrían podido esclarecer ciertos crímenes sin que ello hubiera tenido que conllevar condena alguna, pues la ley de amnistía lo habría impedido. Como subraya Gil: "la amnistía no impide la investigación y constatación de los hechos [...], sino que por el contrario, la constatación por el tribunal de estos supuestos es condición para su aplicación". Y sigue: "Esta interpretación acercaría más nuestra ley de amnistía a un mecanismo de averiguación de la verdad" (Gil 2009: 86). Sin embargo, por lo que se conoce, el resto de los afectados no inició persecución judicial alguna, ya que "[l]as propias víctimas entendieron que la amnistía cubría los casos no juzgados y sin necesidad de que los presuntos autores probasen ni reconociesen nada" (Gil 2009:101). A la vista de este ejemplo, llama la atención la falta de iniciativa de jueces, abogados y fiscales en España, pues, frente a lo ocurrido en otros países, muy pocos se propusieron asesorar a las familias de las víctimas sobre los recovecos que contenía la ley para conseguir, ya que no justicia, sí, al menos, verdad.

${ }^{28}$ No solo Chile ha conseguido investigar el pasado a pesar de la vigencia de la amnistía, sino que Brasil, otro país con el que también se ha comparado a España por su forma elusiva de abordar el pasado, se está cuestionando la vigencia de dicha amnistía y está impulsando importantes avances en términos de justicia y verdad. De hecho, un juez brasileño ha decidido "llevar a cabo el primer juicio contra miembros de la dictadura militar por crímenes cometidos entre 1964 y 1985. Los acusados son dos miembros del ejército jubilados, el Coronel Sebastiao de Moura y el Comandante Licio Maciel, acusados de secuestros durante la eliminación del movimiento guerrillero de Araguaia entre 1972 y 1975. El juez ha acordado con los fiscales que la ley de amnistía de 1979 [...] no es de aplicación en este caso porque los cuerpos de las víctimas secuestradas nunca han sido encontrados, por lo que los casos siguen abiertos". (http://jurist.org/paperchase/2012/09/ brazil-judge-agrees-to-first-war-crimes-trial-for-members-of-dictatorship.php). 
Los militares argentinos, antes de ceder el poder a los civiles en abril de 1983, aprobaron una amnistía que cubría tanto los actos de la "subversión" como los excesos de la "represión". Esta ley sería anulada por el nuevo gobierno democrático en diciembre de ese mismo año. El presidente Alfonsín consiguió llevar a juicio a varios ex dirigentes militares y a los jefes más destacados de la guerrilla. Aunque en un principio se intentó que los militares fueran juzgados por la propia institución castrense, cuando "el Consejo Supremo de las Fuerzas Armadas resolvió que las órdenes dictadas en el pretendido 'ejercicio de la lucha contra la subversión' eran 'inobjetablemente legítimas', la jurisdicción civil hubo de hacerse cargo del caso" (Tappatá 2005:93). Alfonsín llegó a un acuerdo secreto con los militares para que los juicios no fueran más allá de los nueve miembros de las Juntas y les garantizó que éstos serían, finalmente, indultados. Sin embargo, tanto algunos jueces como las organizaciones de derechos humanos presionaron para que el proceso contra los violadores de derechos siguiera adelante, lo que desencadenó algunos pronunciamientos militares.

Las leyes de punto final (diciembre de 1986) y obediencia debida (junio de 1987) se aprobaron para tratar de poner fin a estos actos de rebeldía y estabilizar la democracia, ya que en diciembre de 1986 había unos 6000 procesos judiciales en marcha (Barahona de Brito 1997:122). Una parte de la judicatura, separándose de los deseos del poder ejecutivo, mostró su rechazo a dicha legislación acelerando los procesos antes de que las leyes entraran en vigor ${ }^{29}$. En octubre de 1989 y enero de 1991, Carlos Menem aprobaría una serie de indultos para los encausados con anterioridad a dichas leyes.

Pero, por un lado, los delitos de apropiación de menores a detenidas y desaparecidas embarazadas nunca estuvieron cubiertos ni por las leyes de punto final y obediencia debida, ni por los indultos de Menem, lo que explica que la justicia argentina siguiera actuando durante los años noventa contra algunos altos cargos de la dictadura. Y, por otro lado, desde 1999 "en distintas cámaras federales del país" se empezaron a llevar a cabo los denominados 'Juicios por la Verdad', cuya "finalidad no es establecer la responsabilidad penal de los involucrados y, por ello, no contemplan la posibilidad de condena", sino que aspiran a proteger el "derecho a la verdad y al duelo" (Tappatá 2005:97).

Es evidente que en Argentina la independencia judicial se ha puesto de manifiesto en varias ocasiones (Acuña 2006:236). A partir de 2001, con la primera resolución judicial sobre la inconstitucionalidad de las leyes de punto final y obediencia debida, se reabrieron los juicios por privación ilegítima de libertad, torturas y asesinatos.

Néstor Kirchner, desde el principio de su mandato, se mostró sumamente dispuesto a mejorar la reparación de las víctimas y a limitar la impunidad de los victimarios, ordenó a los militares la apertura de sus archivos para que se pudiera investigar la represión y "derogó el decreto que impedía las extradiciones de militares" acusados de violacio-

\footnotetext{
${ }^{29}$ Con todo, hay que recordar que la Corte Suprema de Justicia argentina se pronunció a favor de la constitucionalidad de la Ley de Obediencia Debida el 22 de junio de 1987.
} 
nes de derechos humanos (Tappatá 2005:109). Además, instó a los jueces de la Corte Suprema a que declararan inconstitucionales los indultos aprobados por Carlos Menem. Con la revocación final, en junio de 2005, de las citadas leyes, los procesos judiciales cobraron un nuevo impulso.

En tiempos recientes, Argentina ha vuelto a ser pionera a la hora de someter a revisión el pasado. Además de que se está intentando llevar a juicio a los militares que formaron parte de los consejos de guerra, también se están iniciando procesos contra los magistrados que actuaron de modo cómplice, no solo durante la dictadura, sino incluso después. Desde abril de 2011, el Consejo de la Magistratura ha decidido "desentrañar qué papel tuvieron los jueces durante el terrorismo de Estado y cómo actuaron años después, cuando les tocó juzgar a los represores". Para este Consejo, que puede "promover la destitución de magistrados", es prioritario averiguar qué hacían éstos "ante secuestros, torturas y desapariciones o cuando recibían un habeas corpus, y qué hacen en la actualidad si les toca juzgar aquellos hechos" 30 .

Respecto a las comisiones de la verdad, ya se ha indicado que, mientras que en España no ha habido ninguna, tanto en Chile como en Argentina se crearon sendas comisiones nada más comenzar el proceso democrático. Sus respectivos informes fueron muy ampliamente difundidos y contribuyeron a esclarecer los mecanismos de la represión, criticando, sin ambages, las complicidades del sistema judicial con la dictadura.

En Argentina, a pesar de las medidas de gracia y de los intentos del poder ejecutivo por detener la persecución judicial, prácticamente nunca han dejado de instruirse casos ni de celebrarse juicios. Ese no ha sido el caso de Chile y menos aún el de España. Con todo, en ambos países se han aprobado recientemente medidas muy interesantes, dando inicio a lo que algunos han denominado una etapa de justicia "post-transicional" (Aguilar 2008b; Collins 2010).

En Chile, a finales de los años noventa se ha producido un "giro procesal". Desde entonces, "los jueces han sentenciado a más oficiales del régimen militar que los jueces de cualquier otro país latinoamericano" (Huneeus 2010:100). Hay al menos tres factores que tener en cuenta a la hora de entender las medidas que se han puesto en marcha en Chile recientemente. Primero, a pesar de que el Gobierno presidido por Frei trató de poner límites a la justicia, una reforma en la Corte Suprema y el nombramiento de nuevos jueces hicieron que dicho órgano a partir de 1997 comenzara a modificar sus decisiones, sosteniendo que "el Derecho internacional tenía primacía sobre la ley de amnistía y que una desaparición es un delito que permanece hasta que se encuentra el cadáver, lo que significa que no puede ser objeto de amnistía hasta que se resuelva" (Barahona de Brito 1997:148).

Segundo, muchos han insistido en el revulsivo que supuso el arresto en Londres de Pinochet solicitado por Garzón. El sistema judicial chileno se sintió avergonzado por no

\footnotetext{
${ }^{30} \mathrm{http}: / / \mathrm{www}$. patriagrande.com.ve/temas/internacionales/investigan-argentina-magistrados-fueron-complices-opresores/ (Fecha de consulta: 26 de febrero de 2013).
} 
haber sido capaz de lidiar con los crímenes de su dictadura y reclamó para sí el derecho a hacerlo en su país. Según Huneeus (2010:101), "muchos jueces vieron en la persecución judicial de los casos de la era de Pinochet una forma de redimir a la judicatura de su pasada complicidad con el régimen y de su baja valoración en las encuestas".

Y tercero, aunque Collins no niega la importancia de las dinámicas internacionales, considera que los factores internos han sido más determinantes para explicar los recientes desarrollos; sobre todo las "acciones estratégicas por parte de actores internos favorables al rendimiento de cuentas y con conocimientos legales, junto con el cambio en el sistema judicial que los países experimentan con el paso del tiempo". Asimismo, "una receptividad judicial mayor hacia las demandas de rendimiento de cuentas" ha demostrado tener gran importancia (Collins 2010:2, 3 y 220).

En España, aunque también se han experimentado cambios recientes en las políticas hacia el pasado (Aguilar 2008b), poco ha cambiado la situación en términos estrictos de justicia y de verdad; y la ley de amnistía, aunque ha adquirido cierta notoriedad en los últimos tiempos, no es previsible que se vaya a modificar ${ }^{31}$ y menos aún a anular ${ }^{32}$.

Con posterioridad a la transición, el salto cualitativo más importante tuvo lugar durante la primera legislatura presidida por Rodríguez Zapatero (2004-2008), debido a la aprobación, a finales de 2007 , de la conocida como "ley de memoria histórica". ${ }^{33}$ Básicamente, se cubren algunas de las lagunas más importantes respecto a la reparación material de las víctimas, se otorgan subvenciones a las asociaciones dedicadas a la recuperación de la memoria y a las exhumaciones de fosas comunes, se ordena a la retirada de símbolos franquistas y se facilita el acceso a la documentación. Sin embargo, no se aprovechó esta ley para anular, o al menos revisar, las sentencias dictadas por los consejos de guerra franquistas. ${ }^{34}$ Aunque el Gobierno en un principio pensó que podría dar satisfacción a esa demanda, trasladó una consulta a la Abogacía General del Estado, que se mostró totalmente contraria a la revisión de juicios y la anulación de sentencias. Como la mayoría del Parlamento hizo suya esta opinión, la ley finalmente aprobada lo único que hizo es declarar "ilegítimos" ciertos tribunales y sentencias del franquismo, ofreciendo la posibilidad de obtener una "declaración de reparación y reconocimiento personal" a los que padecieron determinadas resoluciones judiciales al amparo de leyes dictadas por motivos ideológicos o de creencia religiosa.

\footnotetext{
${ }^{31}$ La única iniciativa relevante a este respecto ha sido una proposición de ley de modificación de la ley de amnistía presentada el 30 de abril de 2010 por el Grupo Mixto y rechazada por el Parlamento el 22 de julio de 2011.

${ }^{32}$ Sin embargo, la Corte Europea de Derechos Humanos había establecido en su Informe Anual de 2009 que la amnistía era incompatible con la obligación de los Estados de investigar los casos de tortura, considerados crímenes de derecho internacional.

${ }^{33}$ Ley $52 / 2007$, de 26 de diciembre, por la que se reconocen y amplían derechos y se establecen medidas en favor de quienes padecieron persecución o violencia durante la guerra civil y la dictadura.

${ }^{34}$ Las otras limitaciones de esta ley, que también fueron ampliamente criticadas, caen fuera de la temática central de este artículo.
} 
Esta decisión no es solo contraria a la opinión del Consejo de Europa, que ha criticado duramente la ausencia de garantías de los consejos de guerra ${ }^{35}$, sino también a la de la mayoría de los españoles ${ }^{36}$ y no tiene en cuenta los precedentes internacionales ${ }^{37}$. Asimismo, frente a la posición del Gobierno, avalada por varias sentencias del Tribunal Supremo ${ }^{38}$ y del Tribunal Constitucional ${ }^{39}$, se han alzado algunas voces cualificadas, aunque minoritarias, en el mundo jurídico partidarias de proceder a anular juicios y sentencias. Joan Queralt, Catedrático de Derecho Penal, argumentó, antes de la aprobación de la Ley 52/2007, a favor de la anulación de las citadas sentencias, de acuerdo con el precedente alemán ${ }^{40}$. José Antonio Martín Pallín, antiguo magistrado de la Sala Segunda del Tribunal Supremo, ha sostenido que la ley permitirá llevar a cabo recursos individuales y que las sentencias consideradas ilegítimas podrán ser anuladas de facto ${ }^{41}$. Carlos Jiménez Villarejo, ex Fiscal Jefe Anticorrupción, ha pedido a la judicatura valentía a la hora de aplicar la ley, y le ha solicitado que lidere el proceso judicial de cancelación de sentencias franquistas ${ }^{42}$. Y Juan José del Aguila (2012) ha subrayado que ni siquiera se ha cancelado el juicio contra Grimau, a pesar de que ha quedado inequívocamente demostrado que el Vocal Ponente del consejo de guerra era un impostor y no tenía, como era preceptivo, el título de abogado.

Por lo que se refiere a la vigencia de la ley de amnistía española, lo cierto es que durante muchos años ha pasado desapercibida. La creación en 2000 de la Asociación para la Recuperación de la Memoria Histórica, responsable de la mayoría de las exhumaciones, dio lugar a las primeras protestas respecto a las restricciones que imponía esta ley para revisar el pasado y reparar a las víctimas. Pero lo que realmente hizo que esta norma recabara una gran atención fue el auto dictado por Garzón el 16 de Octubre

\footnotetext{
${ }^{35}$ Consejo de Europa. Parliamentary Assembly. "Need for international condemnation of the Franco regime". Doc.10737. 4/11/2005.

${ }^{36}$ En una encuesta del CIS de abril de 2008 (n. ${ }^{\circ} 2760$ ), la mayoría de los españoles (un 50,4 \% a favor frente a un 19,3\% en contra), está de acuerdo con que "la democracia debería anular los juicios políticos que tuvieron lugar bajo el franquismo".

${ }^{37}$ En 1998 el Parlamento alemán aprobó una Ley federal que declara nulas las sentencias injustas del nazismo. En Austria, también se han aprobado Leyes anulando sentencias injustas que tuvieron lugar durante la ocupación alemana.

${ }^{38} \mathrm{La}$ Sala de lo Militar del Tribunal Supremo se ha negado, en todas las ocasiones, salvo en una muy excepcional (la de una persona juzgada dos veces por el mismo delito), a revisar las sentencias de los tribunales franquistas. Marc Carrillo ha discrepado de la actuación del Tribunal Supremo y ha señalado que "antes de denegar el recurso se debe agotar la actividad probatoria si hay algún indicio de prueba y no rechazar el recurso aludiendo que la prueba presentada es insuficiente" (recogido por Gil 2009: 60-61).

39 "Nuestro Tribunal Constitucional ya ha dejado clara la imposibilidad de aplicar la Constitución a actos anteriores a su entrada en vigor que ya hayan agotado sus efectos" (Gil 2009: 58).

40 "Desmemoria histórica", Diario El País, 5/1/2007, p. 26.

${ }^{41}$ Diario Público, 20/10/2007, p. 11.

${ }^{42}$ Diario Siglo XXI, 18/10/2007.
} 
de 2008. Hasta entonces ni siquiera se había producido un debate sobre la imprescriptibilidad de determinados delitos, ni sobre la obligación, de acuerdo con Naciones Unidas y varios tratados internacionales ratificados por España, de ofrecer reparación material y moral a todas las víctimas de la violencia durante la guerra civil y la dictadura ${ }^{43}$.

La reciente proliferación de asociaciones de recuperación de la memoria ha sido extraordinaria. A partir de diciembre de 2006 presentaron distintas denuncias ante la Audiencia Nacional respecto a lo que mayoritariamente calificaron como "detenciones ilegales" y "desapariciones forzosas" —ambas consideradas, también por la mayoría de los denunciantes, como crímenes de lesa humanidad - que tuvieron lugar como consecuencia del golpe de Estado del 18 de julio de 1936. Garzón se declaró competente para investigar dichas denuncias. Aunque, una vez que se demostró que los principales responsables de los crímenes mencionados no estaban vivos, Garzón se inhibió en favor de los juzgados territoriales, poco después el Pleno de la Sala de lo Penal de la Audiencia Nacional resolvió igualmente que Garzón no era competente (Chinchón 2012 a y b).

Algunos meses más tarde, se presentaron dos querellas particulares contra Garzón en las que se afirmaba que había incurrido en prevaricación cuando al principio se declaró competente para investigar los delitos. Resulta revelador que los denunciantes estuvieran ligados a organizaciones de extrema derecha: Falange Española y Manos Limpias. El 14 de mayo de 2010 Garzón fue suspendido cautelarmente de sus funciones en la Audiencia Nacional argumentándose que había suficiente evidencia de que había prevaricado al tratar de iniciar investigaciones por los crímenes del franquismo a sabiendas, entre otras cosas, de que la ley de amnistía no permitía hacer tal cosa.

El 23 de febrero de 2012 el Tribunal Supremo resolvió el procedimiento abierto contra Garzón absolviéndole del delito de prevaricación. Sin embargo, consideró todas las tesis defendidas por Garzón como "erróneas". La posición del Tribunal Supremo se ha concretado en la imposibilidad de realizar cualquier tipo de investigación judicial penal sobre los crímenes de la guerra civil y el franquismo. Por otra parte, el 28 de marzo de ese mismo año, el Tribunal Supremo resolvió el conflicto de competencia planteado por los juzgados de Granada y El Escorial; aunque en este Auto se reafirmó en lo decidido en la sentencia de febrero, ha dejado la puerta abierta a poder practicar ciertas diligencias en el orden penal respecto a los restos de las personas "desaparecidas".

\footnotetext{
${ }^{43}$ Adicionalmente, el Comité de Derechos Humanos de Naciones Unidas instó a España en 2008 a que revocara la ley de amnistía; a que adoptara medidas para que los tribunales no consideraran prescritos los crímenes contra la humanidad; a que valorara la posibilidad de crear una comisión de expertos que estableciera la verdad sobre los derechos humanos violados durante la guerra civil y el franquismo; y a que permitiera a las familias exhumar e identificar a las víctimas de las fosas comunes, ofreciéndoles, cuando fuera apropiado hacerlo, compensaciones económicas. Comité de Derechos Humanos. Sesión 94. Ginebra, 13 a 31 Octubre de 2008.
} 


\section{CONCLUSIONES}

Se ha resumido la principal evidencia empírica que demuestra que el sistema judicial español colaboró directamente en la intensa y extensa represión política llevada a cabo por el franquismo. También se han expuesto los mecanismos institucionales creados por el Ejecutivo para asegurarse la lealtad de la profesión judicial.

En los casos chileno y argentino, a pesar de la complicidad judicial, estos casi nunca formaron parte de consejos de guerra y, por lo tanto, no dictaron condenas a muerte. Tampoco participaron en jurisdicciones especiales dedicadas a la represión. Además, tanto en Chile como en Argentina "hubo jueces que buscaron la justicia de forma decidida incluso cuando la deferencia parecía ser la única estrategia racional para aquellos interesados en su carrera profesional. En no pocos casos, esta independencia de criterio les costó sus puestos de trabajo" (Barros 2008:177). Los jueces chilenos han contribuido a esclarecer los hechos sin por ello contravenir la ley de amnistía y en muchos casos han investigado delitos que consideran imprescriptibles de acuerdo con la legislación internacional. La interpretación de la amnistía en España, junto con la ausencia de mecanismos alternativos de esclarecimiento de la verdad, convierten a este país en un modelo de "olvido absoluto" (Gil 2009:86).

A medida que las democracias analizadas se consolidaban, iban surgiendo nuevas dinámicas que hacían posible modificar los acuerdos fundacionales relativos a las políticas de JT. Este ha sido el caso en Argentina y en Chile, pero solo limitadamente el de España, donde: a) la iniciativa social ha sido siempre más débil y ha recibido mucho menos apoyo legal de la profesión; b) ha existido menos sensibilidad a los desarrollos del derecho internacional contrarios a la impunidad y a la prescripción de ciertos delitos ${ }^{44} ; y$ c) los jueces se siguen mostrando reticentes a indagar en el pasado. No son partidarios de revisar y/o anular los juicios injustos del franquismo, defienden la aplicación de la amnistía sin llevar a cabo investigaciones que permitan esclarecer la verdad, se niegan a personarse en las exhumaciones ${ }^{45}$ y ni siquiera reclaman los

\footnotetext{
${ }^{44}$ Algunos expertos afirman que el Tribunal Supremo "se ha mostrado totalmente refractario a cualquier consideración fundada, a cualquier aplicación y a toda interpretación normativa acorde con el Derecho Internacional, en general, y con el Derecho Internacional de los Derechos Humanos, en particular" (Chinchón, Vicente y Moreno 2012:118). Véase también Chinchón (2012a y 2012b).

${ }^{45}$ Según algunas informaciones, "los jueces no quieren encargarse de las fosas del franquismo"; de hecho, "ningún juez se ha acercado nunca a la exhumación a 'datar' o 'identificar' esos restos" (Diario El País 20/09/2012). Y ello a pesar de que en el mencionado auto del Tribunal Supremo se decía que, el hecho de que no hubiera posibilidad alguna de persecución penal, no debería ser obstáculo para se instara a los jueces de instrucción locales a "la práctica de las diligencias dirigidas a datar aquellas acciones criminales y, si fuera necesario, a la identificación de los afectados, para proceder luego, consecuentemente, en derecho. Pues si hay algo inobjetable desde cualquier punto de vista [...] es que los restos de quienes hubieran sufrido muertes violentas no pueden permanecer en el anonimato ni fuera de los lugares pro-
} 
informes forenses ${ }^{46}$. Todo ello constituye una clara anomalía en comparación con lo que ocurre en otros países ${ }^{47}$.

Es sorprendente que en la amplísima literatura existente sobre los procesos de democratización en general, y la transición española en particular, se haya prestado tan poca atención al papel desempeñado por el sistema judicial heredado del régimen anterior. Sin embargo, se trata de una variable fundamental para entender los complejos equilibrios que se producen entre los legados del pasado y las nuevas reglas, instituciones y actores que empiezan a entrar en juego. En la literatura sobre los determinantes de la JT tampoco se ha otorgado suficiente importancia a la resistencia que puede ofrecer un sistema judicial no depurado y, sin embargo, cómplice de la represión, a la hora de crear comisiones de la verdad, encausar a los responsables de violaciones de derechos, y revisar/anular las sentencias judiciales injustas del pasado.

A pesar de que en España la colaboración del sistema judicial con la represión fue muy superior y que se mantuvo durante muchos más años, ciertas medidas de JT continúan siendo impensables. $Y$, si bien es cierto que la resistencia en la transición pudo haber sido tanto político-judicial como social, los datos disponibles demuestran que, hoy en día, los españoles serían partidarios de que se adoptaran medidas de este tipo ${ }^{48}$. Una vez que el relevo generacional ha contribuido a atenuar el trauma de la guerra civil y el miedo a la inestabilidad política (variables cruciales en la transición: Aguilar 2008a), los jueces continúan resistiéndose a revisar las sentencias judiciales del pasado y a personarse en las exhumaciones, mientras que el poder legislativo tampoco parece dispuesto a aprobar medidas que faciliten estas tareas. Y es que no es lo mismo impulsar determinadas políticas de JT cuando solo la cúpula militar y policial de un país ha sido responsable de las prácticas represivas, que cuando una parte no desdeñable de sus profesionales jurídicos ha colaborado en la represión. Los jueces tampoco parecen dispuestos a exponerse a una revisión pública tan crítica de su comportamiento bajo la dictadura como la que puede leerse en los informes de muchas de las comisiones de la verdad ${ }^{49}$.

pios de enterramiento" (Tribunal Supremo. Sala de lo Penal. Auto resolviendo cuestión de competencia. 28/03/2012).

${ }^{46}$ Según Francisco Etxeverría, médico forense encargado de buena parte de las exhumaciones que han tenido lugar en España (Diario El País, 20/02/2010).

${ }^{47}$ La pasividad del sistema judicial español ha hecho que los familiares de las víctimas hayan acudido a la justicia argentina; en el momento de redactarse este artículo, existe una causa abierta en Argentina, la n. ${ }^{\circ} 4591 / 2010$, por delitos de lesa humanidad cometidos por el régimen franquista entre la Guerra Civil y las elecciones de 1977. En España se ha creado una red de apoyo a dicha causa denominada Red AQUA (Red Ciudadana de Apoyo a la Querella Argentina: http://redaqua.wordpress.com/).

${ }^{48} \mathrm{En}$ una encuesta del CIS de abril de 2008 (n. ${ }^{\circ} 2760$ ), la mayoría de los españoles (un 48,7\% a favor frente a un $26,7 \%$ en contra), está de acuerdo con que "las autoridades que violaron derechos humanos bajo el franquismo, deberían ser llevadas a juicio".

${ }^{49}$ Más allá de la fallida iniciativa que tuvo lugar en 2007 ("Valencia lanza una Comisión de la Verdad sobre el franquismo", Diario El País, 10/02/2007), Garzón es el único juez español que me consta que ha solicitado 
También es cierto que el franquismo trató de involucrar al máximo de sectores posibles en la represión. Ello permitió que se acabaran creando sólidas redes de complicidad, lo que explica que fueran tantos quienes salieron ganando de la generosa mirada hacia delante en que consistió, a estos efectos, la transición ${ }^{50}$. Eran muchos los que no tenían alicientes para escrutar el pasado, y quienes sí los tenían, bien por desconfianza hacia el sistema judicial, bien porque entendieron que las prioridades eran otras, apenas presentaron denuncias. También es cierto que, en contraste con lo ocurrido en otros casos, las víctimas no recibieron el imprescindible apoyo legal que se requiere para saber qué procesos se pueden iniciar, cómo presentar los recursos y de qué forma sortear los obstáculos legales.

La represión franquista no habría sido posible sin la implicación del sistema judicial. La dictadura, además, al ser la más longeva de las tres, dispuso de más tiempo para adoctrinar y perpetuar hábitos de dependencia ideológica, lo que ayuda a explicar el conservadurismo del sistema judicial y su resistencia a revisar el pasado, ya que esto supondría, además de exponer públicamente su implicación en la represión, someter a crítica las malas prácticas judiciales y la falta de garantías de la mayoría de los juicios políticos que se llevaron a cabo.

Otras variables contribuyen a explicar los actuales límites españoles en términos de JT. La falta de voluntad política y judicial, la debilidad de las asociaciones de víctimas solo tardíamente asesoradas por profesionales del derecho-, y el escaso conocimiento de derecho internacional entre la judicatura española (Sáez Valcárcel, 2010; Chinchón, 2012a), han demostrado ser fundamentales una vez que la democracia se ha consolidado. Sin embargo, la complicidad judicial con la larga y brutal represión dictatorial aún contribuye a explicar parte de la resistencia que todavía se encuentra en sectores de la judicatura a someter a revisión la maquinaria represiva del franquismo.

La principal conclusión de este artículo es que, ceteris paribus, cuanto más "legal" haya sido la represión, mayor habrá sido la implicación del sistema judicial en ella, y mayor resistencia existirá a aprobar ciertas medidas de JT, al menos durante los procesos de democratización. Habría que comprobar en otros casos si también ocurre que, cuando el sistema judicial no se ha depurado (o se ha hecho de forma tardía e insuficiente) y se caracteriza por un fuerte espíritu de cuerpo, reforzado por un cierto nivel de endogamia, los jueces tienden a establecer mecanismos de lealtad intergeneracional que les lleven a dificultar medidas de JT que podrían poner en entredicho la honorabilidad pasada -y, por tanto, también presente- del colectivo.

la creación de una comisión de la verdad en España para esclarecer los crímenes del franquismo (Diario El País, 14/04/2012).

${ }^{50}$ Agradezco a Mónica Lanero que compartiera conmigo su interesante idea sobre la "cohesión en torno al secreto". Según ella, la estrategia franquista consistió en tejer una serie de complicidades entre los distintos colectivos involucrados en la represión. Ello explicaría que, con posterioridad, muchos de ellos optaran por protegerse mutuamente. Algunos de los principales estudiosos de la represión franquista, como Michael Richards (1998:9), Julián Casanova (2002:38) y Francisco Espinosa (2002:90) han hablado de la existencia de un "pacto de sangre" entre los distintos sectores implicados en ella. 


\section{REFERENCIAS BiBLIOGRÁFICAS}

Acuña, C. H. 2006. "Transitional Justice in Argentina and Chile: A Never-Ending Story?." Pp. 206-238 en Retribution and Reparation in the Transition to Democracy, editado por J. Elster. Cambridge: Cambridge University Press.

Águila, J. J. del. 2001. El TOP. La represión de la libertad. Barcelona: Planeta.

Águila, J. J. del. 2012. "La jurisdicción de guerra del franquismo". Comunicación al Taller 7 del XI Congreso de Historia Contemporánea. Granada, 12 al 15 de septiembre del 2012.

Aguilar, P. 2008a. Políticas de la memoria y memorias de la política. Madrid: Alianza.

Aguilar, P. 2008b. "Transitional or Post-transitional Justice? Recent Developments in the Spanish Case." South European Society \& Politics 4:417-433.

Álvaro Dueñas, M. 1990. "Los militares en la represión política de la posguerra: la jurisdicción especial de responsabilidades políticas hasta la reforma de 1942." Revista de Estudios Políticos 69:141-162.

Barahona de Brito, A. 1997. Human Rights and Democratization in Latin America. Oxford: Oxford University Press.

Barahona de Brito, A. 2001. "Truth, Justice, Memory, and Democratization in the Southern Cone." Pp. 119-160 en The Politics of Memory. Transitional Justice in Democratizing Societies, editado por A. Barahona de Brito, P. Aguilar y C. González. Oxford: Oxford University Press.

Barros, R. 2002. Constitutionalism and Dictatoship. Pinochet, the Junta, and the 1980 Constitution. Cambridge: Cambridge University Press.

Barros, R. 2008. "Courts Out of Context: Authoritarian Sources of Judicial Failure in Chile (1973-1990) and Argentina (1976-1983)." Pp. 156-179 en Rule by Law. The Politics of Courts in Authoritarian Regimes, editado por T. Ginsburg y T. Moustafa. Cambridge: Cambridge University Press.

Bastida, F. 1986. Jueces y franquismo. El pensamiento político del Tribunal Supremo en la Dictadura. Barcelona: Ariel.

Benito, A. B. 2009. "Poder judicial, responsabilidad legal y transición a la democracia en España." Foro Internacional 195:163-199.

Casanova, J. 2002. "Las caras del terror." Pp. 19-41 en Morir, matar y sobrevivir. La violencia en la dictadura de Franco. Barcelona: Crítica.

Chinchón, J. 2012a El tratamiento judicial de los crímenes de la Guerra Civil y el franquismo en España. Una visión de conjunto desde el Derecho internacional. Bilbao: Ed. Universidad de Deusto.

Chinchón, J. 2012b. "The challenges posed to the recent investigation of crimes committed during the Spanish Civil War and Francoism." Pp. 132-158 en The Role of Courts in Transitional Justice. Voices from Latin America and Spain, editado por J. Almqvist y C. Espósito. Oxford-Nueva York: Routledge International.

Chinchón, J., Vicente, L. y A. Moreno. 2012. "Algunos comentarios sobre los argumentos y conclusiones jurídico-internacionales del Tribunal Supremo español en la Sentencia de 27 de febrero de 2012." Espacio Abierto (Revista del Centro de Investigación y Estudios Judiciales) 16:105-118. 
Collins, C. 2010. Post-Transitional Justice. Human Rights Trials in Chile and El Salvador. University Park: The Pennsylvania State University Press.

Constable, P. y A. Valenzuela. 1991. A Nation of Enemies. Chile Under Pinochet. NY: W.W.Norton \& Company.

Elster, J. 2004. Closing the Books. Transitional Justice in Historical Perspective. NY: Cambridge University Press.

Elster, J. 2006. Retribution and Reparation in the Transition to Democracy. Cambridge: Cambridge University Press.

Espinosa, F. 2002. "Julio de 1936. Golpe militar y plan de exterminio." Pp. 53-119 en Morir, matar y sobrevivir. La violencia en la dictadura de Franco. Barcelona: Crítica.

Espinosa, F. ed. 2010. Violencia Roja y Azul. España, 1936-1950. Barcelona: Crítica.

Fernández, A. I. 1995. "El resurgir de la sociedad civil y la aparición de disensiones en el aparato del Estado: el caso de Justicia Democrática (1970-1978)." Pp. 65-75 en Historia de la transición y consolidación democrática en España (1975-1986), vol. 1, editado por J. Tusell. Madrid: UNED/UNAM.

Geddes, B. 1999. "What do we Know About Democratization After Twenty Years?." Annual Review of Political Science 2:115-44.

Gil, A. 2009. La justicia de transición en España. Barcelona: Atelier.

Gil, P. 2010. "Derecho y ficción: la represión judicial militar." Pp. 251-368 en Violencia roja y azul. España, 1936-1950, editado por F. Espinosa. Barcelona: Crítica.

Ginsburg, T. y T. Moustafa. 2008. Rule by Law. The Politics of Courts in Authoritarian Regimes. Cambridge: Cambridge University Press.

Gobierno de Chile. 1991. Comisión Nacional de Verdad y Reconciliación. "Informe Rettig (Capítulo IV, apartado A). Actitud general del Poder Judicial frente a las violaciones a los derechos humanos." Santiago de Chile: Ministerio del Interior y Seguridad Pública.

Gómez Alén, J. y R. Vega García. Coords. 2010. Materiales para el estudio de la abogacía antifranquista. 2 vols. Madrid: Ediciones GSP. Fundación Abogados de Atocha.

Gor, F. 1996. "De la justicia franquista a la constitucional." Pp. 332-332 en Memoria de la transición, coordinado por Joaquín Prieto, Santos Juliá Díaz y Javier Pradera. Madrid: Taurus.

Hilbink, L. 2007. Judges Beyond Politics in Democracy and Dictatorship. Cambridge: Cambridge University Press.

Huneeus, A. 2010. "Judging from a Guilty Conscience: The Chilean Judiciary Human Rights Turn." Law \& Social Inquiry 35:99-135.

Huntington, S. P. 1991. The Third Wave. Democratization in the Late Twentieth Century. Londres: University of Oklahoma Press.

Iglesias, M. A. 2003. La memoria recuperada. Madrid: Aguilar.

Informe CONADEP [1984] 1997. Nunca Más. Buenos Aries: Eudeba.

Jiménez Villarejo, C. 2011. “Una aproximación a la 'policía política' del franquismo: la Sexta Brigada de 
Barcelona." Pp. 197-216 en Enrique Ruano. Memoria viva de la impunidad del franquismo, editado por A. Domínguez. Madrid: Universidad Complutense de Madrid.

Justicia Democrática. 1978. Los jueces contra la dictadura (justicia y política en el franquismo). Madrid: Túcar Ediciones.

Lanero, M. 1996. Una milicia de la justicia. La política judicial del franquismo (1936-1945). Madrid: Centro de Estudios Constitucionales.

Lira, E. 2006. "The Reparations Policy for Human Rights Violations in Chile." Pp. 55-101 en The Handbook of Reparations, editado por Pablo de Greiff. Oxford: Oxford University Press.

Magalhães, P., C. Guarnieri e Y. Kaminis. 2006. "Democratic Consolidation, Judicial Reform, and the Judicialization of Politics in Southern Europe." Pp. 138-196 en Democracy and the State in the New Southern Europe, editado por R. Gunther, N. Diamandouros y D. Sotiropoulos. Cambridge: Cambridge University Press.

Mir, C. 2000. Vivir es sobrevivir. Lleida: Milenio.

Nalepa, M. 2010. "Captured Commitments: An Analytic Narrative of Transitions with Transitional Justice." World Politics 62:341-80.

O'Donnell, G., P. Schmitter y L. Whitehead. 1986. Transitions from Authoritarian Rule. Baltimore: The Johns Hopkins University Press.

Olsen, T., L. Payne y A. Reiter. 2010. "The Justice Balance: When Transitional Justice Improves Human Rights and Democracy." Human Rights Quarterly 32:980-1007.

Ortiz, M. 1996. Violencia política en la Il República y en el primer franquismo. Madrid: Siglo XXI.

Pereira, A. 2005. Political (In)Justice. Authoritarianism and the Rule of Law in Brazil, Chile, and Argentina. Pittsburgh: University of Pittsburgh Press.

Richards, M. 1999. Un tiempo de silencio. La guerra civil y la cultura de la represión en la España de Franco, 1936-1945. Barcelona: Crítica.

Rodrigo, J. 2003. Los campos de concentración franquistas. Madrid: Siete Mares.

Ruiz, J. 1985. La justicia en España. Madrid: Ediciones Libertarias.

Sáez Valcárcel, R. 2010. "Los jueces y el aprendizaje de la libertad, a propósito de los crímenes del franquismo." Mientras Tanto, 114: 41-72.

Sartorius, N. y A. Sabio. 2007. El final de la dictadura. Madrid: Temas de Hoy.

Serrano, M. D. 1993. La pena capital en el sistema español. Madrid: UNED.

Sikkink, K. 2011. The Justice Cascade. Nueva York: W.W.Norton \& Company.

Tappatá, P. 2005. "El pasado, un tema central del presente." Pp. 85-113 en Verdad, justicia y reparación. Desafíos para la democracia y la convivencia social, editado por Gilda Pacheco, Lorena Acevedo y Guido Galli. San José: IDEA/IIDH.

Toharia, J. J. 1975. El juez español. Madrid: Tecnos.

VV.AA. 1976. Comentario Sociológico, Confederación Española de Cajas de Ahorros, 12-13: 1014. 
Paloma Aguilar es doctora en Ciencias Políticas y Sociología por la UNED, y doctora y máster por el Centro de Estudios Avanzados en Ciencias Sociales del Instituto Juan March. Entre sus publicaciones destacan: Memoria y olvido de la guerra civil española (Alianza Editorial, 1996; traducido al inglés y al griego); Políticas de la memoria y memorias de la política (Alianza Editorial, 2008); es coeditora, junto con Alexandra Barahona de Brito y Carmen González Enríquez, de The Politics of Memory. Transitional Justice in Democratizing Societies (Oxford University Press, 2001; traducido al español y al portugués). Ha publicado, entre otras, en las siguientes revistas: Comparative Political Studies, Politics \& Society, Democratization, West European Politics, South European Society \& Politics, History and Memory, Matériaux pour l'histoire de notre temps, Ricerche di Storia Política, Revista Española de Investigaciones Sociológicas, Revista Internacional de Sociología, Revista Internacional de Filosofía Política y Claves de Razón Práctica. Forma parte del Consejo Editorial de las revistas South European Society \& Politics y Memory Studies, y es miembro del Consejo Asesor de la Revista Internacional de Sociología.

RECIBIDO: 14/11/2011

ACEPTADO: 01/04/2012

Publicado on-line: 02/04/2013 